\title{
Toward Building New Sino-Dutch Green Partnerships
}

\author{
Wim Geerts
}

\section{Introduction}

The 2021 is a crucial year in the global fight against climate change, with the Climate COP26 in Glasgow, UK, in November and the Biodiversity COP15 in Kunming, China, in Q4. We need to deliver results to make sure the Paris Agreement can be fully implemented and show that the world is not backtracking on its commitment to reaching climate goals due to the crisis caused by COVID-19. The Netherlands stays fully committed to the goals set in the Paris Agreement and stands ready to work together with China and others to encourage greater ambition in both COPs.

Like many other countries, the Netherlands very much welcomed President Xi's speech during the United Nations General Assembly on September 22, 2020, in which he announced that China will strive to become carbon neutral by 2060 and to peak its $\mathrm{CO}_{2}$ emissions by 2030, as well as the more concrete 2030 targets announced by the president at the virtual Climate Ambition Summit in December 2020. If we are to reach the climate goals of the Paris Agreement, we need China to be a frontrunner.

At last year's Two Sessions, the 14th Five-year Plan was adopted, and although this plan does not set new commitments to reach the 2060 carbon neutrality goal or to peak $\mathrm{CO}_{2}$ emissions earlier than 2030, we have high hopes that China will enhance its policy ambitions through its sectoral five-year plans and the national peak action plan.

The Netherlands and China are already working together in many areas linked to climate goals. We have a long history in energy cooperation, especially in offshore wind, and have cooperated extensively to make agriculture more sustainable and improve food quality. We have also worked intensively on water management, in areas including sponge cities and river basin monitoring, environment and transport, and last but not least, we have seen strong growth in scientific collaboration over the years.

W. Geerts $(\bowtie)$

Embassy of the Kingdom of the Netherlands to the People's Republic of China, Beijing, China 
Especially now, in these times of economic turbulence and geopolitical change, it is important that we continue to invest in our relationship and join forces to deal with the challenges ahead, and climate change is the most important global challenge of our time.

In this article, we will look at current collaborative efforts and explore areas for the future cooperation. To put this into context, I will first explain which commitments the Netherlands and the EU have made in order to reach the climate goals of the Paris Agreement.

\section{Netherlands National Climate Agreement and EU Green Deal}

In 2019, the Netherlands launched its national Climate Agreement, with the following commitments:

- By 2030, we aim to achieve a reduction in greenhouse gas emissions (GHG) by $49 \%$ compared to 1990 levels;

- By 2050, we aim to achieve a reduction in GHG of $95 \%$ compared to 1990 levels; as for electricity generation, our target is to be $100 \% \mathrm{CO}_{2}$ neutral in 2050 .

Our national Climate Agreement was supplemented by the Dutch-integrated National Energy and Climate Plan 2021-2030 (NECP), which contains the main priorities of the climate and energy policy for the next ten years.

At the same time, the European Union has announced its Green Deal, in which it pledges to reach climate neutrality by 2050. With this Green Deal, the European Union is showing leadership and is setting an example: It has stepped up its domestic commitments, adopting an objective of climate neutrality by 2050 and enhancing its short-term GHG emission reduction target to at least 55\% by 2030 compared to 1990 .

To reach these ambitious targets, a lot of work needs to be done in all aspects of the economy, including:

- investing in environmentally friendly technologies;

- supporting industries to innovate;

- rolling out cleaner, cheaper and healthier forms of private and public transport;

- decarbonizing the energy sector;

- ensuring buildings are more energy-efficient;

- working with international partners to improve global environmental standards.

In transitioning toward a climate neutral economy, China, the EU and the Netherlands are facing similar opportunities and challenges. That is why, we need to keep sharing knowledge and continue establishing green partnerships. 


\section{Energy Cooperation}

As previously mentioned, China and the Netherlands have a long history in energy cooperation, especially in the offshore wind sector. Dutch companies are strongly involved in the energy transition in China. Among these efforts, the following are especially notable:

- Wind Power: Around 20 Dutch companies are already active in the offshore

wind sector. Now, that wind turbines for offshore wind farms are getting bigger, and the location of the wind farms is getting further away from the coast, and Dutch expertise in doing complex projects on sea can contribute to technical solutions;

- Clean Energy and Energy Storage: Since hydrogen became a new topic in clean energy and energy storage solutions, we have been actively providing platforms for Sino-Dutch cooperation on hydrogen. The Dutch hydrogen energy sector has teamed up in a Partners for International Business (PIB) project with outstanding Dutch companies and knowledge institutions aiming to develop and implement $\mathrm{H} 2$ energy application demonstration projects in China. In this respect, a large-scale fact-finding mission was organized together with the UNDP to explore cooperation opportunities in southern China, and many of these companies also participated in the UNDP H2 Conference in the city of Foshan.

We have now entered a new decade where the time has come to transition from fossil fuels to renewables. Burning coal for energy production, even in its cleanest form, is no longer a viable economic option, with low prices for renewables, nor is it a Paris proof avenue.

Sustainability, affordability and reliability are key in the development of the offshore wind in the Netherlands. For a better positioning of offshore wind in the energy system, both in the Netherlands and internationally, the advancement and introduction of technical innovations in the offshore wind market are vital. One of the ways we are stimulating technical innovation is through the Offshore Wind Innovation Challenge, which is already in its fourth year. Through this challenge, start-ups and small businesses can apply to find a solution to one of the challenges that leading companies in the offshore wind sector have formulated. This year's Offshore Wind Innovating Challenge is aimed at finding less expensive and more efficient ways of monitoring biodiversity in Offshore Wind Farms and at creating the perfect artificial reef. 
The Netherlands is also strong in sustainable construction, using energy-efficient technologies and solutions. We have already begun discussions and are cooperating with several Chinese cities on promoting circular economic growth, smart city development and zero-waste urban development. There is a mutual benefit in making cities more green and emissions-free.

In the Netherlands, we are committed to creating a carbon neutral environment by 2050 . In the last few years, over 450 innovation projects have begun, focusing on issues ranging from solar power technology, reduction in energy consumption, sustainable heating and cooling systems and smart IT solutions.

\section{A More Sustainable Food System}

The Netherlands and China face similar global challenges when it comes to agriculture, feeding their populations with relatively limited arable land, while tackling climate change. This is especially true in the Netherlands as half of the country's land is below sea level. The food industry accounts for nearly one-third of global GHG emissions and consumes large amounts of natural resources.

The Netherlands supports the EU farm-to-fork strategy, which is a part of the EU Green Deal. The European Commission has set targets to reduce pesticide use by $50 \%$ by 2030 and nutrient losses by $50 \%$ by 2030 to improve water and soil quality. China and the Netherlands have a long history of cooperation in making agriculture more sustainable and improving food quality.

Sustainability is both good for the planet and profit, as it can improve competitiveness and resilience. In the Netherlands, this transition in sustainability is both driven by both companies and research institutes. This valuable knowledge exchange creates solid business cases. This success has been expanded to China, with the Dutch Farm Training Center in pig production and the Sino-Dutch Dairy Development Center. Wageningen University and Research Center is also working closely with Chinese universities.

In the aftermath of the hugely disruptive African swine fever, China is on the eve of redesigning its pig sector. China has the ambition to steadily develop pork production and make the industry more sustainable. A consortium of 14 Dutch companies and knowledge institutes has started working on the development of an innovative, responsible and animal-friendly growth model for the pig farming sector in China. The first achievement is the construction of a Research Test and Training Center (RTTC) in Anping, where Dutch knowledge and expertise will be applied to create better living conditions for people and animals in and around the Chinese pig farming sector.

They are using this state-of-the-art center to help guide China into the future with more sustainable production methods and equipment, like decreasing the use 
of energy by using ventilation systems that are close to energy neutral and reducing emissions by using biological air wash installations.

There is also strong cooperation between China and the Netherlands in dairy production. In November 2013, China Agricultural University, Wageningen University and Research Center and Dutch company FrieslandCampina launched the SinoDutch Dairy Development Center (SDDDC) in Beijing. Since then, ten more partners have joined this center, from both the Netherlands and China. The objective of the center is to improve dairy production, safety and quality levels throughout the entire dairy chain in China. This includes the reduction of emissions at dairy farms by, for example, manure separation treatment to close the nutrient cycle and improvements in feeding practices to reduce ammonia emissions from cows.

The Dutch greenhouse horticulture sector also works with the PIB NL Protected Agri-Alliance China to develop and implement integral and sustainable high-tech greenhouse horticulture agroparks near metropolitan areas. In the Dutch experience, it is possible to replace pesticides in greenhouses by using the natural enemies of insects and micro-organisms to combat pests and plant diseases. Dutch companies and research institutes have applied their knowledge to reduce pesticide emissions from horticulture and contribute to the goal of reducing pesticide use to protect water and soil.

The Netherlands welcomes Chinese efforts in environmentally friendly agriculture to use resources more efficiently and promote soil and water conservation. Dutch agriculture is well-known for its quality and resource efficiency, and the Dutch agrifood sector is working well with Chinese counterparts to develop a more sustainable food system in China.

\section{Cooperation on Water Management, Environment and Transport}

China and the Netherlands have a longstanding relationship in the field of water management, the environment and transportation. In a fast-changing world, in which China plays a pivotal role, cooperation in these areas serves as a tool for mutual learning and development that can contribute to progress in both China and the Netherlands.

For instance, over a decade ago, the Dutch Ministry of Infrastructure and Water Management and the Chinese Ministry of Water Resources (MWR) started to work together in a concrete, problem-oriented spirit of cooperation to learn from each other. Future cooperation between the Netherlands and China will shift from classical water management-related topics to an integrated approach of climate adaptation.

During the Climate Adaptation Summit in January 2021, hosted by the Netherlands, China underlined the equal importance of mitigation and adaptation and the importance of adaptation on a global scale. Furthermore, China stated that it had formulated a national strategy of adapting to climate change for 2035 to make the 
country more resilient to climate risks. It underlines the importance of adaptation as well as an integrated approach in urban planning and water management in China and the Netherlands. Cooperation in this field will increase through deepened policy and knowledge exchanges. In environmental cooperation, the Netherlands is a member of the China Council for International Cooperation on Environment and Development, which will become more important in advising the Chinese central government as environmental issues become more acute.

In the transport sector, rapid developments are taking place that have the potential to improve sustainability and contribute to lowering emissions. Developments on new energy and new technologies for ships, zero emissions in urban freight vehicles, zero carbon port development and railway freight are only a few of the topics that are important and need bilateral and multilateral cooperation to accelerate the reform process.

\section{Scientific Collaboration}

The Netherlands is one of the most important countries for science. All of our universities are listed in the top 200 of the Times Higher Education Ranking, and we consistently rank among the top five countries in the OECD's list of most innovative countries. An important reason for that is that industry, academia and tertiary education institutes are very closely connected and open to cooperation. We also rank fourth in the world in terms of the number of citations per paper, a proxy for the overall quality of our scientific production. Another success factor is that our country is very open to international cooperation, both in science and innovation.

Scientific collaboration with China has grown strongly over the years. Nowadays, all research universities and many universities of applied sciences have ongoing collaborations with Chinese counterparts. These collaborations vary from joint Ph.D. programs to visiting fellowships and full-blown joint research projects. There are about 5,000 Chinese bachelor and master students at our universities and another 500 Ph.D. students.

Some examples of scientific collaboration include:

- LIAMA institute, in which the Center for Mathematics and Computer Sciences (CWI, Amsterdam), CAS Institute of Automation and INRIA from France cooperate. This institute is dedicated to joint research projects in applied mathematics and dates back to 1997. Its research focuses on trustworthy computing, multi-modal sensing and scene understanding and computational models for earth and life sciences. The institute has generated a dozen joint research projects in these areas, with the support of both governments.

- The Sino-Dutch Summer School on semiconductors, which brings together the 40 most brilliant Ph.D. students in semiconductors from both countries for a week of lectures by the most experienced professors and researchers. Besides the obvious academic interest, this is an excellent tool to foster people-topeople relations. 
- The Dutch Council for Scientific Research (NWO) has set up a co-funding program with the Chinese Academy of Science (CAS) to support research projects in the area of vertical farming. Already, two large-scale projects have been approved for funding for the coming four years. Within this program, researchers and industrial partners from both countries will work together to tackle challenges on among others energy-efficiency, crop sciences and prediction models.

\section{Looking Ahead}

The Dutch priorities and objectives for COP26 are in greening financial flows, clean energy, adaption and resilience, nature-based solutions and clean road transport. Under the umbrella of our clean energy priorities, the following points are most relevant:

- We play an active role in the Powering Past Coal Alliance (PPCA) to phase out the use of coal in the world's energy mix and phase out international coal finance. We would like to see China adopt its ambitions and join the Alliance;

- The Netherlands is also active in (research on) carbon capture, utilization and storage (CCUS). For its further deployment, we can share learnings from the Port of Rotterdam $\mathrm{CO}_{2}$ Transport Hub and Offshore Storage Project (Porthos), the first large-scale industrial cluster of CCS;

- On April 15, 2021, the Netherlands co-hosted the World Circular Economy Forum where the crucial role of the transition to a circular economy in achieving the Paris goals was discussed. By designing out waste, avoiding pollution and keeping materials in use as long as possible, it is possible to reduce climate emissions by about $20 \%$. To achieve climate neutrality, it is important to look beyond energy-efficiency, and all work toward a circular shift across the world.

For COP15, the Netherlands hopes that negotiations can resume soon, so that we can adopt a post-2020 global biodiversity framework in Kunming in 2021. Our country is working to this end in concert with the other member states of the European Union.

The Netherlands would like the new framework to include a focus on making international trade sustainable and on the role of the financial sector. Besides cost prices, food safety and food security, trade and industry also need to take more account of their impact on biodiversity.

We stand ready to build new Sino-Dutch green partnerships to face our common challenges. 


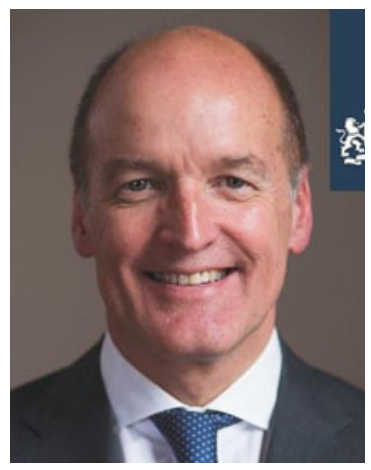

H.E. Mr. Wim Geerts is the ambassador of the Kingdom of the Netherlands to the People's Republic of China. He has been the ambassador to China since 2019. Mr. Geerts was born in 1963 and graduated from Nijmegen University and Boston College with a Master's Degree in English language and literature. Mr. Geerts entered the Foreign Ministry in 1988. He served as Deputy Chief of Mission at the Embassy of the Kingdom of the Netherlands in Washington DC, Deputy Director General Political Affairs, Ambassador to Canada and Director General Political Affairs successively. Before taking office in Beijing, he was the Secretary General of Defense.

Open Access This chapter is licensed under the terms of the Creative Commons AttributionNonCommercial-NoDerivatives 4.0 International License (http://creativecommons.org/licenses/bync-nd/4.0/), which permits any noncommercial use, sharing, distribution and reproduction in any medium or format, as long as you give appropriate credit to the original author(s) and the source, provide a link to the Creative Commons license and indicate if you modified the licensed material. You do not have permission under this license to share adapted material derived from this chapter or parts of it.

The images or other third party material in this chapter are included in the chapter's Creative Commons license, unless indicated otherwise in a credit line to the material. If material is not included in the chapter's Creative Commons license and your intended use is not permitted by statutory regulation or exceeds the permitted use, you will need to obtain permission directly from the copyright holder.

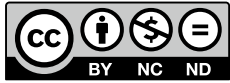

